\title{
(JIPD)
}

Jurnal Inovasi Pendidikan Dasar

Vol. 4, No. 1, Bulan Januari Tahun 2020, Hal. 57-61

E-ISSN: 2598-408X, P-ISSN: 2541-0202

http://unikastpaulus.ac.id/jurnal/index.php/jipd

\section{PENINGKATAN KEMAMPUAN MEMBACA DAN MENGHITUNG SISWA KELAS TINGGI DI SDI KENDA MELALUI TAMBAHAN JAM PELAJARAN}

\author{
Mariana Jediut, Fransiska Jaiman Madu, \& Asterius Juano \\ Program Studi PGSD Universitas Katolik Indonesia Santu Paulus, \\ Jln Jend. Ahmad Yani No 10 Ruteng-Flores 86508 \\ Email: marianajediut90@gmail.com
}

Diterima: 11 Januari 2020 , Direvisi: 15 Januari 2020, Diterbitkan: 31 Januari 2020

\begin{abstract}
Abs tract: This research is motivated by the low aptitude of elementary student which is related to the learning materials in counting and reading in Kenda Public Elementary School. This study intends to describe the effectiveness of learning in additional time for the students who have low ability in counting and reading. The type of this research is using action research. That action is taken repeatedly and in every action is begun with the planning, giving treatment (action), observation, and reflection. Grounded on the upshot of this research, giving an additional hour of learning for the students who have difficulty in reading and counting could be narrated effective. This is shown in the grade that achieved by the students in every meeting, wherein the upgrading of giving treatment I, II, and III.
\end{abstract}

Keywords: reading and counting

\begin{abstract}
Abstrak: Penelitian ini dilatarbelakangi oleh rendahnya kemampuan siswa sekolah dasar berkaitan dengan materi pembelajaran menghitung dan membaca di SDI Kenda. Adapun tujuan penelitian ini adalah untuk mendeskripsikan keefektifan tambahan jam pelajaran bagi siswa yang memiliki kemampuan rendah terkait menghitung dan membaca. Jenis penelitian yang digunakan adalah penelitian tindakan (Action Research). Tindakan tersebut dilakukan secara berulang-ulang dan setiap tindakan diawali dengan perencanaan, pemberian treatmen (tindakan), observasi, dan refleksi. Berdasarkan hasil penelitian, pemberian tambahan jam pelajaran bagi siswa yang berkesulitan membaca dan menghitung dapat dikatakan efektif. Hal ini terbukti pada nilai yang diperoleh siswa pada setiap pertemuan, yakni adanya peningkatan dari pemberian treatmen I, II, dan III.
\end{abstract}

Kata Kunci: membaca dan menghitung

\section{PENDAHULUAN}

Kemampuan membaca dan menghitung merupakan kemampuan dasar yang harus dimiliki setiap peserta didik. Untuk itu, pembelajaran membaca dan menghitung harus dimulai sejak dini, yaitu jenjang SD khususnya di kelas rendah. Membaca merupakan suatu kegiatan yang kompleks karena melibatkan sembilan aspek yakni sensori, perseptual, urutan, pengalaman, pikiran, pembelajaran, asosiasi, sikap, dan gagasan (Rahim, 2008). Hal ini berarti keterampilan membaca siswa harus selalu diasah, baik di kelas rendah maupun kelas tinggi.
Anak yang memiliki keterampilan membaca akan memperoleh informasi yang lebih banyak dibandingkan dengan anak yang tidak memiliki keterampilan membaca. Untuk itu, kemampuan membaca setiap siswa harus selalu ditingkatkan. Dalam pembelajaran membaca, guru harus menyediakan teks bacaan. Hal ini bertujuan agar siswa mudah dalam latihan membaca, sehingga pembelajaran membaca dapat dilakukan secara efektif.

Selanjutnya menghitung adalah usaha melakukan, mengerjakan hitungan seperti menjumlah, mengurangi serta manipulasi bilangan-bilangan dan lambang-lambang 
matematika (Pratiwi 2015). Dengan demikian, menghitung biasanya dilakukan anak dengan membilang yang selanjutnya melakukan operasi hitung bilangan. Dalam mengajarkan berhitung kepada anak guru harus melakukannya dengan cara yang menyenangkan secara bertahap dengan memperhatikan prinsip-prinsip berikut (Depdiknas 2007).

a. Pembelajaran berhitung diberikan secara bertahap, diawali dengan menghitung benda-benda atau pengalaman peristiwa kongkrit yang dialami melalui pengamatan di alam sekitar.

b. Pengetahuan dan keterampilan pada pembelajaran berhitung diberikan secara bertahap menurut tingkat kesukarannya, misalnya dari kongkrit ke abstrak, mudah kesukar, dari sederhana ke yang lebih kompleks.

c. Pembelajaran berhitung akan berhasil jika anak-anak diberi kesempatan berpastisipasi dan dirangsang untuk menyelesaikan masalah-masalahnya sendiri.

d. Pembelajaran berhitung membutuhkan suasana yang menyenangkan dan memberikan rasa aman serta kebebasan bagi anak.

e. Bahasa yang digunakan di dalam pengenalan konsep berhitung permulaan sebaiknya bahasa yang sederhana dan jika memungkinkan mengambil contoh yang ada dilingkungan sekitar anak.

f. Dalam pembelajaran berhitung anak dapat mengelompokkan sesuai tahap penguasaannya

g. yaitu tahap konsep masa transisi dan lambang.

Jadi, berdasarkan tujuan dan prinsip-prinsip di atas, dalam pembelajaran berhitung siswa harus diberi kesempatan untuk memanipulasi berbagai objek nyata sehingga mudah memahami materi. Objek nyata yang digunakan bertujuan sebagai jembatan antara yang konkret dengan yang abstrak.

Berdasarkan uraian di atas, siswa yang berada pada kelas tinggi di jenjang SD harus sudah mengusai kemampuan membaca dan menghitung karena dalam pembelajaran di kelas rendah, siswa dibekali dengan kemampuan tersebut. Namun, kenyataan yang terjadi di SDI Kenda adalah masih ditemukannya siswa kelas tinggi yang belum memiliki keterampilan membaca dan menghitung. Hal ini diketahui berdasarkan observasi awal peneliti.oleh karena itu diperlukan solusi untuk mengatasi masalah tersebut. Salah satu solusi yang dapat diakukan adalah melakukan tambahan jam pelajaran bagi siswa yang berkesulitan membaca dan menghitung. Tambahan jam pelajaran ini dilakukan secara bertahap hingga semua siswa yang berkesulitan mengalami peningkatan kemampuan. Selain itu tambahan jam pelajaran tersebut dilakukan di luar jam pembeljaran efektif di SDI Kenda.

\section{METODE}

Jenis penelitian yang digunakan adalah penelitian tindakan (Action Research). Penelitian tindakan merupakan bentuk penyelidikan yang bersifat memperbaiki suatu kondisi dengan turut serta berpartisipasi di dalamnya dengan bekerja sama memanfaatkan berbagai informasi yang terkumpul sebagai bahan untuk merefleksi. Tindakan tersebut dilakukan secara berulangulang dan setiap tindakan diawali dengan perencanaan, pemberian treatmen (tindakan), observasi, dan refleksi.

1. Perencanaan

Pada tahap perencanaan, peneliti menyiapkan berbagai media yang dapat digunakan pada saat pembelajaran, menetukan metode atau teknik, dan membuat rancangan pembelajaran.

2. Tindakan

Pada tahap ini, peneliti memberikan treatment berupa tambahan jam pelajaran bagi siswa yang berkesulitan dalam membaca dan menghitung.

3. Observasi

Observasi bertujuan untuk melihat sejauh mana perubahan kemampuan siswa dalam membaca dan menghitung.

4. Refleksi

Refeksi dilakukan untuk menentukan apakah siswa yang diberi perlakuan perlu mengikuti treatmen pada tahap berikutnya atau tidak.

\section{HASIL PENELITIAN DAN PEMBAHASAN}

Sebelum memberikan tambahan jam pelajaran bagi siswa yang berkesulitan membaca dan menghitung, terlebih dahulu dilakukan penjaringan data awal terhadap siswa kelas tinggi di SDI Kenda. Penjaringan data tersebut dilakukan dengan cara memberikan tes membaca dan memngitung kepada siswa. Berdasarkan penjaringan data, dari 24 orang yang mengikuti tes ditemukan ditemukan 7 orang yang 
berkesulitan membaca dan 10 orang yang berkesulitan mengitung. Oleh karena itu, siswasiswa tersebut perlu diberi jam pelajaran tambahan. Artinya, 7 orang yang berkesulitan membaca dan 10 orang yang berkesulitan menghitung perlu diberi treatment.

\section{Gambaran Proses dan Hasil Penelitian Kemampuan Membaca}

\section{Pelaksanaan Treatment dan Tes 1}

Pada pelaksanaannya, kegiatan tambahan jam pelajaran dilakukan dengan metode latihan. Setelah semua siswa melatih diri, siswa diminta secara individu membacakan teks di depan kelas dengan memperhatika keempat aspek yang dinilai. Peneliti melakukan observasi dan memberikan nilai saat siswa membacakan teks. Selanjutnya diberi tes untuk mengukur kemampuan anak-anak tersebut dan mengukur keefektifan treatmen yang diberikan tim kepada anak-anak. Berdasarkan tes pada tujuh orang siswa, terdapat 4 orang yang perlu dilatih secara khusus karena sama sekali tidak mampu membacakan dengan lancar. Selanjutnya, tim melakukan analisis dan refleksi hasil tes yang dilakukan.

\section{Pelaksanaan Treatmen dan Tes II}

Berdasarkan hasil tes pada treatmen I, dari 7 orang siswa SDI Kenda yang perlu diberi jam tambahan, terdapat 4 orang yang perlu diberi perlakuan secara khusus di luar jam pelajaran (pertemuan II). Dengan kata lain, ke-4 orang siswa tersebut diberi tambahan jam pelajaran karena nilai pada pertemuan I tidak menunjukkan kemampuan di atas standar berdasarkan KKM yang berlaku di sekolah tersebut. Keempat orang siswa tersebut sama-sama mengalami kesulitan pada semua aspek yang dinilai. Artinya, siswa masih mengeja suku kata dan masih terbata-bata saat membaca. Selanjutnya, peneliti membimbing 4 orang siswa yang sama sekali tidak bisa membaca, 1 orang diantaranya adalah anggota tambahan yang tidak mengikuti proses bimbingan tambahan jam pelajaran pada pertemuan sebelumnya karena tidak datang sekolah. Setelah treatmen II dilakukan, selanjutnya tim memberikan tes II pada 4 orang siswa tersebut. Hasil tes menunjukkan bahwa dari 4 orang siswa yang kurang mampu, terdapat 2 orang siswa yang masih memiliki nillai kategori buruk. Tim pun melakukan analisis dan refleksi berdasarkan hasil tersebut. Tim memutuskan untuk melanjutkan bimbingan kepada 2 orang siswa tersebut pada treatmen III.

\section{Pelaksanaan Treatmen dan Tes III}

Berdasarkan hasil tes pada pertemuan II, terdapat 2 orang siswa SDI Kenda yang perlu diberi jam tambahan. Selanjutnya, treatmen III diberikan pada 2 orang siswa yang sama sekali tidak bisa membaca. Oleh karena itu, peneliti menerapkan metode tutor sebaya dan latihan. Langkah-langkah pembelajarannya adalah sebagai berikut.

a. Melakukan kegiatan membacakan teks secara berulang-ulang;

b. Menggarisbawahi kata-kata yang terdapat pada akhir kalimat. Hal ini dilakukan dengan maksud, siswa dapat memperhatikan tanda titik dan tanda tanya yang berada di akhir kalimat.

c. Ukuran tanda titik dan tanda tanya pada akhir kalimat dibuat dengan ukuran yang agak besar.

d. Mengadakan tutor sebaya, yakni menjadikan teman kelas yang lancar membaca, untuk melatih siswa yang sama sekali tidak bisa membaca.

Berdasarkan kegiatan tersebut, sebagian besar siswa mengalami perubahan yang lebih baik. Hasil tes menunjukkan bahwa 2 orang siswa yang kurang mampu tersebut menunjukkan kemajuan yang baik. Oleh karena itu,. Tim memutuskan untuk mengakhiri bimbingan belajar di sekolah tersebut.

\section{Gambaran Proses dan Hasil Penelitian Kemampuan Menghitung}

\section{Pelaksanaan Treatment dan Tes 1}

Pada saat pelaksanaan treatmen I, siswa dibimbing secara individu dan kelompok. Metode yang digunakan adalah permainan. Menurut Dienes (Aisyah dkk., 2007: 2.8), permainan matematika sangat penting sebab operasi matematika dalam permainan tersebut menunjukkan aturan secara kongkret dan lebih membimbing dan menajamkan materi matematika pada anak didik. Oleh karena itu, permainan yang dilakukan siswa harus mempunyai tujuan yang jelas sesuai dengan tujuan pembelajaran. Selain menggunaan metode permainan, dalam kegiatan tersebut juga menggunakan metode latihan. 
Latihan yang berulang menyebabkan perubahan atau kemaajuan bagi siswa. Adapun hasilnya yakni dari 10 siswa yang bekesulitan menghitung terdapat 2 orang siswa yang tidak hadir sehingga siswa yang mengikuti tambahan jam pelajaran hanya 8 orang. Berdasarkan hasil tes setelah diberi tambahan jam pelajaran, terdapat beberapa siswa yang mengalami kemajuan baik dalam mengurutkan bilangan, melakukan operasi hitung, maupun operasi pengurangan. Hasil tes tersebut menunjukkan dari 8 siswa yang diberi tambahan jam pelajaran, terdapat 3 orang siswa yang memperoleh nilai 4 , 1 siswa yang memperoleh nilai 8 , sedangkan 6 siswa lainnya memperoleh nilai 10 . Setelah tim menganalisis dan merefleksi hasil tes tersebut, tim memutuskan untuk memberikan tambahan jam pelajaran lanjutan pada 3 orang siswa yang memperoleh nilai 4 .

\section{Pelaksanaan Treatmen dan Tes II di SDI Kenda}

Pada kegiatan ini, bimbingan secara individu dilakukan pada 3 orang siswa yang masih mengalami kesulitan dalam menghitung. Hal ini juga dibantu oleh siswa yang sudah mengalami kemajuan dalam menghitung. Bimbingan secara individu dan bantuan teman sejawat tersebut dapat memberikan kemajuan bagi siswa yang mengalami kesulitan. Akan tetapi, ke 3 orang siswa yang diberi tambahan pelajaran tersebut, terdapat 2 orang yang masih lamban dan perlu dibimbing kembali. Tim pun melakukan analisis dan refleksi terhadap hasil tes tersebut dan memutuskan untuk melanjutkannya pada treatmen III.

\section{Pelaksanaan Treatmen dan Tes 3}

Pada kegiatan ini, bimbingan secara individu dilakukan pada 2 orang siswa yang masih mengalami kesulitan dalam menghitung. Hal ini juga dibantu oleh siswa yang sudah mengalami kemajuan dalam menghitung. Keduanya lebih baik dan tidak mengalami kendala. Hal ini menunjukkan ada perubahan atau kemajuan bagi siswa yang mengalami kesulitan menghitung. Oleh karena itu, tim memutuskan untuk mengakhiri kegiatan pada sekolah tersebut.

Berdasarkan hasil penelitian yang telah dilakukan, peneliti merekomendasikan metode yang dapat diterapkan dalam pembelajaran membaca dan menghitung. Salah satu metode yang dapat diterapkan adalah tutor sebaya. Tutor sebaya adalah seorang siswa pandai yang membantu belajar siswa lainnya dalam tingkat kelas yang sama (Aria dkk., 2001:38). Hal ini berarti siswa yang menjadi tutor berkemampuan tinggi dan sudah menguasai materi pelajaran. Adapun langkah-langkah penerapan metode tersebut adalah sebagai berikut.

1) Menyiapkan materi yang berkaitan dengan membaca dan menghitung

Materi tersebut disiapkan guru untuk dipelajari oleh tutor sebaya. Hal ini dilakukan agar sebelum membimbing siswa yang berkesulitan, tutor sebaya sudah menguasai materi berhitung.

2) Menentukan siswa yang akan dijadikan sebagai tutor sebaya

Siswa yang ditentukan sebagai tutor sebaya adalah siswa yang pandai dalam membaca dan menghitung.

3) Guru membimbing tutor sebaya

Bimbingan ini dilakukan agar tutor sebaya mudah menjelaskan materi kepada siswa yang berkesulitan membaca dan menghitung.

4) Siswa yang berkesulitan dibentuk dalam beberapa kelompok

Siswa yang sudah ditentukan sebagai tutor sebaya akan membimbing siswa yang berkesulitan secara berkelompok. Agar bimbingan lebih efektif, sebaiknya setiap kelompok hanya terdiri dari 2 atau 3 siswa.

5) Tutor sebaya membimbing siswa yang berkesulitan membaca dan menghitung Bimbingan dilakukan secara intens agar kemampuan siswa yang berkesulitan membaca dan menghitung dapat meningkat. Dalam hal ini tutor sebaya juga dapat memanfaatkan benda-benda yang sering mereka gunakan untuk dijadikan sebagai media, seperti batu, kelereng, lidi, atau kemiri (khusus pembelajaran menghitung).

6) Guru mengamati proses bimbingan serta memberi pujian kepada tutor sebaya dan siswa yang mengalami peningkatan kemampuan membaca dan menghitung.

\section{KESIMPULAN}

Berdasarkan hasil penelitian yang telah dilakukan, disimpulkan pemberian tambahan jam pelajaran bagi siswa kelas tinggi yang berkesulitan membaca dan menghitung efektif. Hal ini dibuktikan dengan adanya peningkatan pada setiap hasil tes setelah pemberian treatmen I, II, dan III, yaitu pada pembelajaran membaca, 
dari 7 siswa yang mengikuti treatmen I terdapat 4 siswa yang perlu diberi bimbingan pada treatmen II. Dari 4 siswa tersebut, terdapat 2 orang yang perlu dibimbing pada treatmen III hingga 2 siswa tersebut mengalami peningkatan kemampuan membaca. Selanjutnya dari 10 orang yang mengalami kesulitan menghitung, terdapat 3 orang yang perlu dibimbing setelah mengikuti treatmen I sehingga siswa-siswa tersebut mengikuti treatmen II. Berdasarkan tes treatmen II, terdapat 2 siswa yang perlu dibimbing secara khusus pada treatmen III hingga siswa tersebut mengalami perubahan yang lebih baik dalam menghitung.

\section{DAFTAR RUJUKAN}

Aisyah, N., Siti H., Somakim, Purwoko, Yusuf H., \& Masrinawatie. 2007. Pengembangan Pembelajaran Matematika SD. Jakarta: Depdiknas Dirjendikti.

Aria, Djalil dkk.. 2001. Pembelajaran Kelas Rangkap. Jakarta : Depdikbud.

Depdiknas. 2007. Pedoman Pembelajaran Berhitung Permulaan di TK. Jakarta: Depdiknas.

Pratiwi, E. 2015. "Pembelajaran Calistung Bagi Anak Usia Dini antara Manfaat Akademik dan Resiko Menghambat Kecerdasan Mental Anak". Prosiding. Seminar Nasional Pendidikan FKIP Universitas Muhammadiyah Ponorogo dengan Tema Inovasi Pembelajaran untuk Pendidikan Berkemajuan". Yogyakarta, 7 November 2015.

Rahim, F. 2008. Pengajaran Membaca di Sekolah Dasar. Jakarta: Bumi Aksara. 